Digitalizacja archiwalnych numerów czasopisma naukowego Analecta Cracoviensia 1-24 (1969-1992) i ich publikacja w otwartym dostępie - zadanie finansowane w ramach umowy 672/P-DUN/2017 ze środków Ministra Nauki i Szkolnictwa Wyższego przeznaczonych na działalność upowszechniającą naukę

\title{
PRÓBA REINTERPRETACJI „ZAKŁADU” PASCALA
}

Próby uzasadniania teizmu wypracowane w filozofii B. Pascala uważane są często bądź to za wyraz irracjonalnego woluntaryzmu, w którym przyjmuje się tezy mimo braku ich obiektywnych uzasadnień, bądź też za przejaw podejścia ekonomiczno-pragmatycznego, w którym efekty sạ ważniejsze od argumentów. Mimo przyjęcia tezy głoszącej, iż serce widzi dalej niż rozum i posiada dodatkowe prawa, Pascal odległy jest od irracjonalizującego stanowiska, gdzie uwaga skupiona byłaby przede wszystkim na tych elementach teizmu, których nie można objąć racjonalnym dyskursem. Słynny „zakład” Pascala wydaje się przedstawiać jedna $z$ prób racjonalnego uzasadnienia wy boru teizmu. Próba ta odwołuje się zarówno do elementów rachunku prawdopodobieństwa, jak i do kryterium racjonalności ludzkich działań. Samo pojęcie racjonalności jest we współczesnej filozofii nauki dalekie od jednoznacznych określeń. Inne cechy charakterystyczne przysługują racjonalności zdroworozsądkowej, inne racjonalności formalnej, merytorycznej czy metodologicznej ${ }^{\text {. }}$ W wielości rozróżnień poświęconych tej problematyce mówi się nawet o „racjonalności irracjonalnej" 2. Cechą charakterystyczną zakładu Pascala wydaje się jego racjonalność pragmatyczna, przejawiająca się w wyborze środków proporcjonalnych i stosownych do określonego celu. W tym sensie nieracjonalne pragmatycznie są zarówno działania, w których bez obiektywnej potrzeby stosuje się mocne środki do osiągnięcia blahego celu, jak i działania, w których bagatelizuje się cel stosując środki nieproporcjonalnie małe w stosunku do jego obiektywnej wartości.

Wybór stanowiska teistycznego, przejawiający się $\mathrm{w}$ indywidualnej podmiotowej decyzji, bywa nierzadko przeciwstawiany decyzjom racjonalnym i określany jako „skok w ciemnośc”", „zawierzenie mimo paradoksów i absurdu" czy ,irracjonalne zdeklarowanie się". Nie kwestionując możliwości istnienia takich wyborów w poszczególnych przypadkach, chciałbym przeanalizować te elementy akceptacji teizmu, które w ujęciu Pascala jawią się jako racjonalne pragmatycznie.

1 Rozróżnienia typów racjonalności przedstawiam w pracy: Teizm i filozofia analityczna, Kraków 1985.

2 Zob. W. H. N e w t on-Smith, The Rationality of Science, Boston 1981. Trzeci rozdzial tej monografii zaopatrzony jest tytulem: Popper - The Irrational Rationalist. 
W różnych partiach Myśli znajdują się różne warianty Pascalowskiej argumentacji za przyjęciem tezy o istnieniu Boga. Niektóre z tych wariantów, zalecające przyjęcie praktyk i rytów religijnych przed rozstrzygnięciem sporu o istnieniu Boga, spotkały się z zarzutem niemoralnego charakteru ", sformułowania innych wariantów mogą sugerować zajęcie postawy merkantylnej $w$ dyskùsji o transcendencji. Jako przedmiot analiz przyjmijmy argument zawarty w p. 451 Myśli. Pascal pisze tam m.in.: „Skoro trzeba wybierać, zobaczymy, w czym mniej ryzykujesz. Masz dwie rzeczy do stracenia: prawdę i dobro; i dwie do stawienia na kartę: swój rozum i swoją wolę, swoją wiedzę i swoją szczęśliwość; twoja zaś natura ma dwie rzeczy, przed którymi umyka: błąd i niedolę. Skoro trzeba koniecznie wybierać, jeden wybór nie jest $z$ większym uszczerbkiem dla twego rozumu niż drugi. To punkt osądzony. A twoje szczęście? Zważmy zysk i stratę zakładając, że Bóg jest. Rozpatrzmy te dwa wypadki: jeśli wygrasz - zyskujesz wszystko; jeśli przegrasz, nie tracisz nic. Zakładaj się tedy, że jest i bez wahania [...] Tutaj jest nieskończoność życia nieskończenie szczęśliwego do wygrania, szansa wygranej przeciw skończonej ilości szans straty. To, co stawiasz jest skończone. Wybór jest jasny: wszędzie, gdzie jest nieskończoność i gdzie nie ma nieskończonej ilości szans straty przeciw szansie zysku, nie można się wahać, trzeba stawiać wszystko" 4 .

Argumentacji tej nie należy traktować przedmiotowo jako zbioru zdań połączonych związkami wynikania logicznego czy inferencjami o charakterze probabilistycznym. Podejście takie jest nie możliwe zarówno z racji teologicznych, jak i metodologicznych. W perspektywach poznania teologicznego nie można za podstawę argumentów przyjmować kalkulacji ekonomicznych; Bóg, którego opłaca się przyjąć, nie ma nic wspólnegó ani z Bogiem Objawienia, ani z Bogiem filozofów. W perspektywach metodologicznych trzeba zauważyć, że współczynnik prawdopodobieństwa przypisywany poszczególnym konkurencyjnym teoriom na gruncie określonej wiedzy $W$ nie determinuje jednoznacznie prawdziwości lub fałszywości tych teorii. W wyniku rewolucji naukowych przyjmowano teorie (np. Kopernika, Darwina), którym uprzednio przypisywano bardzo niski stopień prawdopodobieństwa. Z kolei teorie uważane przez długi czas za potwierdzone empirycznie załamywały się gwałtownie i są dziś całkowicie zarzucone. Oszacowania wysokiego prawdopodobieństwa nie upo-

8 Zob. J. H. Gill, On Knowing God. New Directions for the Future of Theology, Philadelphia 1981, s. 52. Krytyka dotyczy propozycji zawartych w p. 233 Myśli.

${ }^{4}$ B. Pasca 1, Mysli, Warszawa 1977 , s. $186 \mathrm{n}$; por. też paralelne sformulowania punktów $342-345,452-456,458,522$. 
ważniają w ogólnym przypadku do definitywnych asercji. Nawet gdy w grę wchodzą zdania odnoszące się do faktów jednostkowych, próby argumentacji probabilistycznej są wysoce ryzykowne. Zdania: „Człowiek może nie przyjmować posiłków przez dowolnie długi okres” czy „Spoleczeństwo można dowolnie długo uciskać przy zastosowaniu wyrafinowanych metod policyjnych" są falsyfikowane przez wystąpienie śmierci lub rewolucji bezpośrednio po osiągnięciu przez nie stanu maksymalnej konfirmacji empirycznej. Porównywanie współczynników prawdopodobieństwa może mieć więc tylko pragmatyczną wartość przy ocenie racjonalności poszczególnych działań, nie może natomiast służyć do obiektywnego rozstrzygania problemu.

Pragmatyczne aspekty zakładu Pascala akcentowane są w jego nowych wariantach, które wypracował $\mathrm{m}$. in. I. Hacking i G. Schlesinger ${ }^{5}$. Ujęcia te ukazują zbieżności między stylem dyskursu Pascalowskiego a współczesnymi opracowaniami dotyczącymi racjonalności pragmatycznej. Nawiązując do ich podstawowych idei, odwołajmy się do analogii z zakładami na loterii i przyjmijmy, że prawdopodobieństwo wygranych wynosi dla dwóch różnych losów $l_{1}$ i $l_{2}$ odpowiednio $\mathrm{p}_{1}$ i $\mathrm{p}_{2}$. Koszty losów są równe $k_{1}$ i $k_{2}$, zaś wielkość wygranych $w$ poszczególnych przypadkach $-\mathrm{W}_{1} \mathrm{i} \mathrm{W}_{2}$. Aby ocenić pragmatyczną racjonalność zakładów, trzeba porównać wielkości wynoszące odpowiednio $f\left(l_{1}\right)=p_{1} W_{1}$ - $k_{1}$ oraz $f\left(l_{2}\right)=p_{2} W_{2}-k_{2}$. Jeśli porównanie tych wielkości wykazuje, iż $f\left(l_{1}\right) \gg f\left(l_{2}\right)$ wyrazem pragmatycznej racjonalności będzie zakup losu $l_{2}$. Jeśli więc $\mathrm{w}$ jednym $\mathrm{z}$ porównywanych przypadków prawdopodobieństwo wygrania wynosi $p_{1}=0.5$, wielkość wygranej $W_{1}=10 \mathrm{z}$, zaś koszt biletu $\mathrm{k}_{1}=5 \mathrm{zl}$, to bardziej racjonalny pragmatycznie będzie zakup alternatywnego losu, którego prawdopodobieństwo wygranej wynosi np. $\mathrm{p}_{2}=0.02$, wielkość wygranej $\mathrm{W}_{2}=5000 \mathrm{zł}$, zaś cena losu $\mathrm{k}_{2}=100 \mathrm{zł}$. Porównanie korespondujących czynników prowadzi wówczas do nierówności $0.5 \cdot 10-5 \ll 0.02 \cdot 5000-100$, tzn. $0 \ll 900$.

Ekstrapolując podobne rozumowanie na teren wyboru między interpretacjami teistycznymi oraz ateistycznymi, należałoby ograniczyć się do najbardziej podstawowych twierdzeń przyjmowanych w różnych wariantach tych interpretacji. W ten sposób abstrahowałoby się od różnic, np. między protestantyzmem i katolicyzmem czy różnic między ateizmem Sartre'a i ateizmem Camusa, zaś proponowane alternatywne interpretacje $I_{1} \vee I_{2}$ (gdzie $\dot{\mathrm{v}}$ oznacza funktor alternatywny rozłącznej) miałyby postać: $\mathrm{I}_{1}$ — „Istnieje Bóg dający szczęście wieczne”; $\mathrm{I}_{2}$ — „Nie prawdą jest, że istnieje Bóg i szczęście wieczne”. W przypadku wyboru interpre-

s I. Hacking, The Logic of Pascal's Wager, „Amer. Phil. Quart." (1972) s. 186-192; G. Schlesinger, Religion and Scientific Method, Dordrecht 1977, s. $135-140$. 
tacji $I_{1}$ opisywany przez Pasçala zbiór wyrzeczeń $i$ ofiar $k_{1}$ miałaby relatywnie niską wartość, niewiele wyższą od korespondującej wartości $\mathbf{k}_{2}$, która oznacza wielkość ofiar koniecznych do przyjęcia w perspektywach ateistycznej interpretacji świata $\mathrm{I}_{2}$. Wielkość $W_{1}$, denotująca konsekwencje podmiotowe wyboru alternatywnych interpretacji, przyjmuje $\mathrm{w}_{2}$ wartość nieskończoną $\mathrm{z}$ racji nieskończoności wiecznego szczęścia, podczas gdy $\mathrm{W} \mathrm{I}_{2}$ wartość $\mathrm{W}_{2}$ może być tylko skończona. Biorąc pod uwagę, iż $k_{1}$ jest tego samego rzędu co $k_{\mathrm{p}}$, natomiast $W_{1}=\infty$, gdy $W_{2} \neq \infty$, można wskazać tylko jedną sytuację, w której wybór $\mathrm{I}_{2}$ byłby racjonalniejszy pragmatycznie niż wybór $I_{1}$. Aby zachodziła ta sytuacja, tzn. by $\left.\mathrm{f}\left(\mathrm{l}_{2}\right)\right) \gg \mathrm{f}\left(\mathrm{l}_{1}\right)$, prawdopodobieństwo interpretacji $\mathrm{I}_{1}$ musiałoby być równe zeru. Parametrowi $\mathrm{p}_{1}$ można jednak przypisywać wartość zerową tylko wówczas, gdyby dało się udowodnić, że $p_{z}=1$, tzn. że prawdziwą jest teza: „Nie ma Boga". Ponieważ dowodu takiego ani nikt nie wypracował dotychczas, ani nie widać logicznej możliwości jego wypracowania, trzeba przyjąć, iż $\mathrm{p}_{2} \neq 1$ i konsekwentnie $\mathrm{p}_{1} \neq 0$. Dla wszystkich wartości $p_{1}$ różnych od zera spełniana jest nierówność $\mathrm{p}_{1} \cdot \infty-\mathrm{k}_{1} \gg \mathrm{p}_{2} \cdot \mathrm{w}_{2}-$ - $k_{2}$, wyrażająca $w$ sposób odmienny formalnie treści opisywane przez Pascala w Myślach. Wniosek o racjonalności przyjęcia tezy o istnieniu Boga można by kwestionować, wprowadzając na miejsce jednej wartaści $\mathrm{p}_{1}$ ciąg wartości określających prawdopodobieństwo różnych argumentacji za istnieniem Boga. Gdyby ciąg $\mathrm{p}_{1}, \mathrm{p}_{2} \ldots \mathrm{p}_{\mathrm{n}}$ zdążal do zera, wówczas, iloczyn $\mathrm{p}_{\mathrm{n}} \cdot \infty$ przybierałby wartość nieokreśloną i byloby bezsensowne twierdzenie iż $f\left(l_{1}\right) \gg f\left(l_{2}\right)$. W reinterpretacji takiej mieszano by porządek ontologiczny z porządkiem logicznym, uzasadniając wnioski o charakterze ontologicznym za pośrednictwem dowolnych, pozbawionych obiektywnych racji procedur poznawczych. Niewątpliwie można latwo skonstruować ciąg argumentów teistycznych o malejącej wartości. Ostatni wyraz tego ciągu może mieć wartość zerową, np. gdy będzie nim "dowód" ontologiczny czy argument ex gradibus perfectionis. Istnienie takiego ciągu nie przemawiałoby jednak za irracjonalnością zakładu Pascala, lecz tylko odsłaniałoby metodologiczne - albo nawet psychologiczne - uwarunkowania konstrukcji ciągu. Zdanie „Bóg istnieje” dotyczy bowiem pojedynczego faktu, w stosunku do którego semantycznie bezsensowne jest wprowadzanie ciągu prawdopodobieństw dążącego do zera. Jeśli różne metody oceny prawdopodobieństwa prowadzą do różnych wartości p, wówczas należałoby poddać ocenie same te metody i przeanalizować przesłanki, na podstawie których dokonano oszacowań. Jeśli jakaś $\mathrm{z}$ metod upoważnia do asercji, iż $\mathrm{p}_{1}=0,5$, wówczas wartościowa poznawczo mogłaby być alternatywna metoda wskazująca, iż $p_{1}=0$, ale zupełnie bezwartościowa jest metoda pozwalająca stwierdzić, iż wartość $p_{1}$ jest większa od 0,001 . Z tej racji, iż me todologi- 
cznie niemozliwe jest wykazanie nieistnienia Boga, zakład Pascala zachowuje swą moc nie jako obiektywny argument, lecz jako heurystyczna zasada racjonalnego działania, pozwalająca uniknąć sceptycyzmu w sytuacjach, gdy przeciw argumentom za istnieniem Boga wysuwane są obiekcje niemożliwe praktycznie do sfalsyfikowania.

Tak interpretowany zakład Pascala jest przejawem racjonalizacji wyboru teizmu. Przyjęta w nim metodyka odpowiada metodyce stosowanej: przy uzasadnianiu realizmu poznawczego czy uzasadnianiu tezy o ontycznej racjonalności świata. We wszystkich tych przypadkach można mnożyć dowolnie długo wyszukane sztuczne obiekcje, lecz właśnie obiektywna doniosłość przyjętych twierdzeń stanowi rację uzasadniającą racjonalność podtrzymywania twierdzeń o istnieniu Boga czy realności świata. W argumentacji Pascala można jednak stwierdzić poważne braki, jeśli ocenia się ją z perspektyw teologii. Po pierwsze, $w$ interpretacji tej przyjmuje się implicite, iż nieskończona wartość $W$ jest możliwa do osiągnięcia tylko dla tych, którzy uznają tezę: „Istnieje Bóg”. Założenie to jest niezgodne $\mathrm{z}$ doktryną teologiczną o możliwości zbawienia ateistów i uwzględnianie tej doktryny wymagałoby istotnych modyfikacji argumentu, uwypuklających jeszcze bardziej jego ekonomiczno-kalkulacyjne składowe. Po drugie, proponowanego przez zakład wyboru nie można ujmować w kategoriach intelektualno-wolitywnych działań związanych z akceptacją tezy: „Istnieje Bóg”. Wśród formułowanych w teologii warunków koniecznych do zbawienia wymieniana jest nie tylko akeeptacja twierdzeń teoretycznych, lecz także akceptacja zbioru zasad określających naszą postawę wobec Boga. Pascal uznaje wprawdzie istnienie przynajmniej niektórych tych zasad, pisząc o „kosztach gry”, ale wyrażenie to odnosi się głównie do respektowania zakazów etycznych, jakie stanowią niewielki tylko podzbiór w zbiorze zasad określających postawę człowieka wobec Absolutu. Problematyka miłości, altruizmu czy naśladowania osobowościowych wzorców, tak istotna dla teistycznej wizji życia, pozostaje zarówno poza zasięgiem zakazów etycznych, jak i głównych przesłanek argumentacji Pascala. Po trzecie, Pascalowskie rozumowanie można stosować tylko w odniesieniu do najbardziej podstawowych twierdzeń teizmu. Nie można natomiast na jego podstawie uzasadniać wyboru którejkolwiek $\mathrm{z}$ grup wyznaniowych, gdyż we wszystkich tych grupach $W=\infty$. Zakład może więc pełnić funkcje pragmatyczne tylko w odniesieniu do alternatywy: teizm lub ateizm. Jedną $\mathrm{z}$ bardziej popularnych form eliminowania pierwszego członu tej alternatywy były pozytywistyczne próby wykazywania, że stanowisko teistyczne jest bezsensowne.

Inną próbę wypracowania anty-Pascalowskiego zakładu stanowi argumentacja wykazująca, iż stanowisko to zawiera wewnętrzne sprzeczno- 
ści i z tego powodu należy odrzucić tezę „Istnieje Bóg”, przypisując jej prawdopodobieństwo $\mathrm{p}=0$ i odmawiając tym samym argumentacji $\mathrm{Pa}$ scala wszelkiej wartości pragmatycznej. Stanowisko takie znalazło w. kręgu filozofii analitycznej najpełniejszy wyraz w antydowodzie ontologicznym J.N. Findlaya. Z argumentacji tej wynika, iż Bóg nie mógłby istnieć, gdyby posiadał takie cechy, jaki przypisywano mu $\mathrm{w}$ filozofii klasycznej, zwłaszcza nurtu scholastycznego ${ }^{6}$. Argumentacja ta posiada jednak wszystkie braki metodologiczne, jakie charakteryzowały symetryczną do niej, lecz prowadzącą do przeciwnego wniosku, argumentację św. Anzelma. Próby filozoficznego kwestionowania możliwości pewnych faktów zostały już wystarczająco zdyskredytowane $w$ podejmowanej w przeszłości krytyce mechaniki kwantowej, genetyki czy cybernetyki. W krytyce tej usiłowano również kwestionować realność faktów. na tej podstawie, że nie mieściły się one w określonych schematach pojęciowych. Załamanie się tych krytyk, odsłaniając ich bezpodstawność metodologiczną, sprawia, iż stanowisko Findlaya pozostaje odosobnione we współczesnej filozofii Boga.

Na uwagę zasługuje jeszcze fakt, iż mimo braków zakładu Pascalow-: skiego, modyfikacje tego argumentu można spotkać u wielu autorów przy próbach racjonalnego uzasadniania wyboru wiary. Pragmatyka Pascala znajduje szczególne rozwinięcie w pragmatyzmie W. Jamesa. Łącząc metodologię empiryzmu z założeniami naturalizmu J. Deweya i C. S. Peirce'a, James postuluje ocenę interpretacji teistycznych w świetle praktycznych następstw teizmu. Następstwa te ujmuje on w dwóch płaszczyznach: egzystencjalnej i metodologicznej. W płaszczyźnie egzystencji twórca pragmatyzmu przyznaje, iż teizm wnosi wartości etyczne i kulturowe, które ubogacają naszą cywilizację, uwrażliwiając ją na wartości i ideały. Otwartość na Byt transcendujący dane doświadczenia, wspólnotẹ modlitwy i dążenie do doskonalenia etosu trzeba oceniać pozytywnie, nawet jeśli konkretne wspólnoty wyznaniowe nie są w stanie realizować przyjmowanych przez nie założeń teoretycznych. W płaszczyźnie metodologicznej, mimo sympatii do Deweya i Milla, James zalicza siebie ,razem z większością filozofów do grupy supernaturalistycznej" ". W uza-

6 J. N. Findlay, Can God's existence be disproved, [w:] New Essays in Philosophical Theology, ed. A. Flew, A. M a c Intyre, New York 1964, s. $47-55,71-75$. s. 403 . 
sadnieniu tego wyboru można obok przesłanek empirycznych znaleźć elementy zakładu Pascala. Przesłanki empiryczne, dotyczące przeżyć i doświadczeń religijnych, czynią wysoce prawdopodobną tezę 0 istnieniu transcendentnego bytu, warunkującego te przeżycia. Wykluczenie realności tego bytu byłoby już wynikiem przedzałożeń wchodzących w skład ateistycznej wizji świata. James przeciwstawia się podobnym przedzałożeniom, twierdząc, iż bogata rzeczywistość przeżyć modlitewnych wymaga uwzględnienia dwóch czynników: immanentnego, uzależnionego od podmiotowych predyspozycji, oraz transcendentnego, którego oddziaływań nie można wyjaśnić przez odwołanie do czynników podmiotowych. W przeżyciu tym wydaje się, że ,pozaświatowe energie, jeśli wolicie Bóg, wywołują bezpośrednie efekty w świecie natury, do którego należy reszta naszych doświadczeń" ${ }^{8}$. Konsekwencją uznania realności tego świata powinno być uwzglẹdnienie tezy o ludzkiej nieśmiertelności. Realności życia wiecznego nie można uzasadnić w sposób jednoznaczny, lecz ze względu na praktyczne następstwa tej tezy nie można jej pominąć agnostycznym indyferentyzmem. Jej różne od zera prawdopodobieństwo jest czynnikiem wystarczającym do uznania supernaturalistycznej wizji życia. Szansa zbawienia prowadzi do doniosłych konsekwencji pragmatycznych, gdyż wizja świata, w której głównym elementem jest rezygnacja zostaje zastąpiona przez wizję, w której podstawowym elementem jest nadzieja ${ }^{\circ}$.

Wprowadzenie problematyki teizmu na płaszczyznę pragmatyki i rachunku prawdopodobieństwa prowadzić musi do takich samych oporów, jakie pojawiają się przy ujmowaniu sacrum w kategoriach ekonomiki. Pragmatyczna racjonalność Pascala i Jamesa nie jest jednak przejawem ekonomicznego podejścia do problematyki Absolutu, lecz jest próba racjonalnego przeciwdziałania elementom podmiotowej niepewności obecnej w ludzkim poznaniu. Eliminacja tej niepewności wydaje się niemożliwa de iure, nawet jeśliby dopuściłoby się głębokie przemiany czy to $\mathrm{w}$ zbiorze przyjmowanych obecnie zasad epistemologicznych, czy w zbiorze podstawowych założeń teizmu. Bez względu na to, czy w filozofii poznania preferuje się założenia intuicjonizmu, racjonalizmu czy empiry$\mathrm{zmu}$, zawsze istnieje teoretyczna możliwość zakwestionowania dowolnego twierdzenia, uzasadnionego przy pomocy metod przyjmowanych w którymkolwiek z wymienionych stanowisk. I tak, gdyby teza o istnieniu Boga jawiła się dla ludzkiej świadomości jako bezpośrednio oczywista i nie wymagająca żadnej formy dyskursywnego uzasadniania, mimo wszystko można by nawet wtedy kwestionować jej prawdziwość, kierując się tą samą metodologią, na podstawie której kwestionuje się np. prawdziwość

8 Tamże, s. 406.

Tamże, s. 408. 
tezy o istnieniu możliwości wolnego wyboru u człowieka. Mimo iż w ludzkiej świadomości jest powszechnie doświadczany fakt, że akty poszczególnych wyborów nie mają charakteru całkowicie zdeterminowanego przez czynniki zewnętrzne, gdyż ich ostateczny charakter uzależniony jest od indywidualnych decyzji, to jednak przeciwnicy tezy o wolności woli usiłują wykazywać, że subiektywnie doświadczana wolność jest jedynie iluzją. Możliwość podobnej argumentacji występowałaby w odniesieniu do tezy o istnieniu Boga. Gdyby rzeczywistość miała taką strukturę ontyczną, że teza o istnieniu Boga jawiłaby się w niej jako teza bezpośrednio oczywista, wówczas można by nadal mnożyć obiekcje, iż oczywistość ta ma charakter iluzoryczny i jest bądź to uwarunkowana ewolucyjnie czy genetycznie, bądź też stanowi jedynie przejaw podświadomych ludzkich tęsknot za nieskończonością.

Gdyby mimo pozornego charakteru „dowodu” ontologicznego dało się wypracować odmienne od argumentacji Anzelma argumenty dedukc y jne za istnieniem Boga, wówczas do ich zakwestionowania wystarczyłoby zakwestionowanie przesłanki większej, stanowiącej rację dowodu. Głębokie przemiany, jakie dokonały się w naukach formalnych w ostatnim stuleciu, dają psychologiczną podstawę do kwestiononowania zasad, które w przeszłości uważano za niekwestionowalne. Zakwestionowanie przez G. Cantora tezy głoszącej, iż część musi być mniejsza od całości, podobnie jak powstanie geometrii nieeuklidesowych, naruszających uważany za oczywisty piąty postulat, sprawia, iż nie można a priori wykluczyć prawdopodobieństwa zakwestionowania żadnej z ogólnych zasad uważanych za podstawowe dla współczesnej wizji świata. Tym samym więc istniałaby możliwość dogmatycznego odrzucenia jakiejkolwiek argumentacji dedukcyjnej za istnieniem Boga, nawet gdyby nie występowały w niej paralogizmy występujące w argumencie Anzelma.

Przeciw wszelkim próbom uzasadniania teizmu przy pomocy przesłanek empirycznych można również formułować a priori wielorakie obiekcje. W programowej negacji teizmu przed podjęciem obiektywnej oceny przesłanek będzie się wówczas akcentować fakt, iż zbiór danych empirycznych uzależniony jest od czasu, że z rozwojem badań własności fizyczne, uważane za globalne, okazują się tylko lokalne, że przyszły paradygmat naukowy może przynieść zupełnie różną interpretację tych samych zjawisk etc. Przedmiotowa wartość podobnych obiekcji może być niewielka, ale łączone $z$ nimi podmiotowe konsekwencje mogą okazać się bardzo ważne, znajdując wyraz w agnostycyzmie czy różnych typach sceptycyzmu.

Dodatkowych racji, które przemawiają za racjonalnością argumentu Pascala, dostarcza wzrastająca świadomość ograniczeń i relatywizacji poznania osiąganego w naukach szczegółowych. W ostatnim stuleciu w róż- 
nych wersjach pozytywizmu regułą stało się przeciwstawianie braków i niepewności dyskursu teologicznego niekwestionowalnym twierdzeniom formułowanym w perspektywach poznawczych nauk przyrodniczych. Dopiero w wyniku załamania się programu Koła Wiedeńskiego oraz w następstwie zainicjowanych przez R. Mertona i T. Kuhna dyskusji nad socjologicznymi uwarunkowaniami nauki, uświadomiono sobie iluzoryczny charakter metodologii, w których teorie przyrodnicze czy aksjomaty nauk formalnych uważano za ostateczne i niekwestionowalne.

Współczesne analizy z zakresu filozofii matematyki wykazują, jak wiele jest rozbieżności, elementów niepewnych i uwarunkowanych paradygmatycznie czy kulturowo $\mathrm{w}$ poznaniu matematycznym przedstawianym tradycyjnie jako wzorzec ścisłości i pewności naukowej. Wypowiedzi o „oszałamiającym zamęcie” w „przerażającym labiryncie pojęciowym matematyki" ", podobnie jak próby wprowadzania metod empirycznych do badań matematycznych świadczą o głębokich przeobrażeniach, jakie dokonały się $\mathrm{w}$ naszym stuleciu $\mathrm{w}$ paradygmacie matematyki. Różne wersje teorii rewolucji naukowych wskazują, że przeobrażenia w paradygmacie nauk przyrodniczych są jeszcze głębsze i że z rozwojem nauki zmieniają się nie tylko poszczególne teorie, lecz także podstawowe założenia określające warunki racjonalności, kryteria demarkacji czy reguły wyjaśniania naukowego. Zmiana tych założeń prowadzi nie tylko do istotnie różnych interpretacji tych samych danych empirycznych, lecz nawet do wzajemnie sprzecznych ocen racjonalności poszczególnych interpretacji. W paradygmacie fizyki Arystotelesa za irracjonalne uważano wypowiedzi o ruchu Ziemi czy istnieniu plam na Słońcu, w paradygmacie współczesnej fizyki jako irracjonalne jawią się empiryczne argumenty J. Glanvilla o istnieniu czarownic czy wypowiedzi Akademii Francuskiej wykluczające możliwość, by meteoryty spadały na Ziemię z nieba.

Uwzględnienie sygnalizowanych przejawów ewolucji w paradygmacie nauki nie powinno prowadzić do opowiedzenia się za irracjonalizmem, lecz do krytycznego dostrzeżenia podmiotowych uwarunkowań teorii racjonalności. Świadomość tego, że ,im ściślej pragniemy określić fundament wiedzy naukowej, tym większy otrzymujemy nieład" ${ }^{11}$ nie może prowadzić do zastąpienia interpretacji naukowych nieładem logicznym, lecz powinna prowadzić do uświadomienia zależności ładu logicznego od przyjmowanych $\mathrm{w}$ danym etapie nauki przedzałożeń. Przedzałożenia te są zbiorem ogólnych twierdzeń przyjmowanych implicite i określających najogólniejszą wizję świata, warunki racjonalności, zasady inter-

${ }_{10}$ B. R ussell, Mój rozwój filozoficzny, Warszawa 1971, s. 240.

11 R. G. H. S in, The Tao of Science, An Essay on Western Knowledge and Eastern Wisdom, London 1982, s. 35. 
pretacji naukowej, etc. Zależnie od przyjmowanych przedzałożeń preferuje się w filozofii nauki nurt empiryczny lub spekulatywny, który wykazuje arbitralność scjentyzmu lub bezsensowność metafizyki itp. Przedzałożenia mogą być z zasady przedmiotem krytycznej refleksji; ich ocena implikuje jednak element błędnego koła, gdyż zależy ona w dużym stopniu od przyjmowanych przedzałożeń. Niektóre z podzielanych powszechnie przedzałożeń zostają uświadamiane explicite dopiero ex post w wyniku rozwoju badań. Przed powstaniem geometrii nieeuklidesowych nie uświadamiano sobie arbitralności przedzałożenia o euklidesowym charakterze przestrzeni. Przed odkryciem ekspansji wszechświata twierdzenie o jego statyczności uważano za samooczywisty pewnik. Niekiedy zdroworozsądkowe przedzałożenie podnoszono do rangi podstawowych aksjomatów. Tak było np. z piątym aksjomatem Elementów Euklidesa, który głosił, że część musi być mniejsza od całości. Tezę tę uważano za pewną przez 25 wieków, zaś jej fałszywość wykazał G. Cantor w swych analizach dotyczących zbiorów nieskończonych.

Przyjmowane przedzałożenia są nie tylko zrelatywizowane czasowo i paradygmatycznie, lecz także kulturowo. Zasady metafizyczne, które wydawały się oczywiste dla filozofii rozwijanej w kręgu racjonalizmu greckiego jawią się jako dowolne i hipotetyczne dla myśli Wschodu. Zasadzie racji dostatecznej przeciwstawiana jest $\mathrm{w}$ filozofii chińskiej zasada bootstrapu ${ }^{12}$, regułom sensowności syntaktycznej języków europejskich całkowicie różne reguły języków Hopi czy Hanunoo. W tym kontekście jakakolwiek próba logicznej argumentacji wymaga uprzednio osobowościowego wyboru, który przynajmniej prowadzi do ukrytego uznania określonego słownika, zasad argumentacji, warunków racjonalności czy podstawowych merytorycznych założeń, służących za przesłanki większe argumentacji. Wybór zasad rozumowania, założeń filozofii logiki czy warunków interpretacji naukowej bywa często porównywany do zakładu Pascalowskiego $\mathrm{z}$ tej racji, że zarówno $\mathrm{w}$ zakładzie, jak i w wymienianych wyborach podstawowymi elementami są prawdopodobieństwo wybieranej interpretacji oraz doniosłość analizowanej problematyki.

Jeśli uwzględni się fakt, iż alternatywę w stosunku do wybieranych po pascalowsku interpretacji stanowi sceptycyzm, trzeba przyznać, iż proponowana przez Pascala metodyka ma na celu zastąpienie sceptycyzmu racjona!nością przy rozwiązywaniu najbardziej doniosiych zagadnień. Jej przyjęcie nie zamienia prawdopodobnieństwa w pewność, lecz wskazuje interpretację, którą można uznać za bardziej racjonalną pragmatycznie. Aprobata lub obiekcje wobec prób kierowania się podobną pragmatyką

12 Zob. np. C. F. Chew, Bootstrap: A Scientific Idea, „Science" 161 (1968) s. 762-765; Hadron Bootstrap: Triumph or Frustration, „Phys. Tod.” 23 (1970) s. $23-28$. 
przy rozstrzyganiu alternatywy teizm-ateizm uzależnione są od przedzałożeń określających wizję racjonalności i jej rolę w ludzkich działaniach. Przedzałożenia te mogą ulegać zmianom zarówno w wyniku krytycznej refleksji, jak i w następstwie oddziaływania czynników pozaintelektualnych. Obok refleksji nad alternatywnym zbiorem przedzałożeń, do czynników takich należy zaliczyć $\mathrm{m}$. in. egzystencjalną postawę do Boga jako Osoby, a nie tylko przedmiotu dyskursu, wybrany horyzont aksjologiczny czy stosunek do określonych norm etycznych. Czynniki te przenikają się wzajemnie $w$ sferze przedzałożeń i ich psychologicznych uwarunkowań, wpływając przez to pośrednio na styl filozoficznego dyskursu o Bogu. Ich połączenie sprawia, iż filozof teista uprawia właściwą sobie refleksję nie tylko jako animal rationale, lecz również jako animal axiologicum czy aestheticum. Pascalowska synteźa porządku intelektu z porządkiem serca może nie satysfakcjonować zwolenników jednostronnych rozwiązań, ale syntezie tej nie można zarzucić braku racjonalności, będącej zarówno wyrazem dowartościowania intelektu, jak i otwarcia na rzeczywistość, której nie jest w stanie objąć żaden typ dyskursu. Antropologia implikowana przez zakład Pascala określa właściwe człowiekowi środki racjonalnych działań, chroniąc przed latwym metodologicznie sceptycyzmem. Równocześnie jednak ta sama antropologia, przypominając o istnieniu ponadracjonalnego porządku, przypomina o możliwości ponadracjonalnej więzi z Ontyczną Racją Racjonalności.

\section{AN ATTEMPT AT REINTERPRETATION OF PASCAL'S WAGER}

\section{$\mathrm{Sum} \mathrm{m}$ ary}

The traditional version of Pascal's Wager presented in Pensés has been a subject of multivarious reinterpretations and amendements. The paper presents one of the interpretations revealing elements of pragmatic rationality in choice of Theism. In the approach one emphasizes the point that in the practice of philosophical discourse sophisticated objections could be formulated to any attempt at rational justification of Theism. Even if the thesis of God's existence were self-evident, its veracity could be questioned on the same way as veracity of human experience concerning free will or immaterial character of the self is questioned in some philosophical currents. Any attempt at argumentation for Theism by taking into consideration either empirical data or fundamental rational principles is a subject to sceptical questioning in which one argues that new principles of rationality and entirely new empirical data could be accepted in a future scientific paradigm. Similar anti-Theistic arguments are unfalsifiable and possess no substantial confirmation, nonetheless, they cannot be excluded from methodological point of view. In this context the form of Pascal's Wager reinterpreted in terms of calculus of probability brings a rational counterproposal to agnosticism. 